\title{
Penerapan Model Pembelajaran Sinektik Menggunakan Media Pembelajaran GeoGebra pada Materi Dimensi Tiga
}

\author{
Sunyoto $^{凶}$ \\ SMA Negeri 1 Kediri
}

\section{Info Artikel Abstract}

Sejarah Artikel:

Diterima 11 Mei 2020

Direvisi 17 Mei 2020

Disetujui 20 Mei 2020

Keywords:

Synectic Learning Model,

GeoGebra

Paper type:

Research paper

This study aims: to determine the improvement of student learning outcomes in three dimensions subject through the application of synectic learning models using GeoGebra learning media. This research is a classroom action research. Which consists of two cycles. The subjects are class XII_IPA students, odd semester 2019/2020 SMA Negeri 1 Kediri. In cycle 1 it is discussed about the distance of two points, the distance of points to a line and the distance of two lines, and in cycle two it is discussed about the distance of points to fields, distance of lines to fields and distance of two fields. The results of the study in cycle 1, obtained an average value of 78,75, completeness 81,25\%. As for cycle 2, the average value of 75 completeness is 75\%. It can be seen from cycle 1 to cycle 2 that the result is down due to the very complex cycle 2 material, the difficulty level is indeed different. The student response was very positive, student activity increased. Although classical completeness has not been achieved, the results for researchers are very satisfying. Because the mistakes made by some students are not due to the ability to understand, but the lack of accuracy due to nervousness. The application of the synectic learning model by using GeoGebra learning media on the three dimensional material concluded can improve student learning outcomes, and students respond well.

\begin{abstract}
Abstrak
Penelitian ini bertujuan: untuk mengetahui peningkatkan hasil belajar siswa pada materi dimensi tiga melalui penerapan model pembelajaran sinektik dengan menggunakan media pembelajaran GeoGebra. Penelitian ini merupakan penelitian tindakan kelas. Yang terdiri dari dua siklus. Subyeknya siswa kelas XII_IPA, semester gasal tahun 2019/2020 SMA Negeri 1 kediri. Pada siklus 1 dibahas tentang jarak dua titik, jarak titik ke garis dan jarak dua garis, dan pada siklus dua dibahas tentang jarak titik ke bidang, jarak garis ke bidang dan jarak dua bidang. Hasil penelitian pada siklus 1, didapatkan nilai rata-rata 78,75 , ketuntasan $81,25 \%$. Adapun pada siklus 2 didapat nilai rata-rata 75 ketuntasan $75 \%$.Terlihat dari siklus 1 ke siklus 2 hasilnya turun diakibatkan materi siklus 2 sangat komplek, tingkat kesulitannya memang beda. Adapun respon siswa sangat positif, keaktifan siswa meningkat. Walaupun ketuntasan secara klasikal belum tercapai, namun hasil itu bagi peneliti sangatlah memuaskan. Karena kesalahan-kesalahan yang diperbuat beberapa siswa bukan karena kemampuan pemahaman, tetapi ketidak telitian akibat grogi. Penerapan model pembelajaran sinektik dengan menggunakan media pembelajaran GeoGebra pada materi dimensi tiga disimpulkan dapat meningkatkan hasil belajar siswa, dan siswa merespon dengan baik.
\end{abstract}

(C) 2020 Universitas Muria Kudus

p-ISSN 2615-4196

e-ISSN 2615-4072

Program Studi Pendidikan Matematika

Fakultas Keguruan dan Ilmu Pendidikan Universitas Muria Kudus

Kampus UMK Gondangmanis, Bae Kudus Gd. L. It I PO. BOX 53 Kudus

Tlp (0291) 438229 ex.147 Fax. (0291) 437198

E-mail: sunyoto.kdr@gmail.com 


\section{PENDAHULUAN}

Pada kurikulum 2013 materi dimensi tiga merupa kan materi matematika kelompok wajib yang diberikan di kelas XII_IPA SMA semester gasal. Sebagaimana tercantum dalam Permendikbud tahun 2016 nomor 24 lampiran 16, pada Kompetensi Dasar(KD) 3.1 Mendes kripsikan jarak dalam ruang (antar titik, titik ke garis, dan titik ke bidang) dan 4.1 Menentukan jarak dalam ruang (antar titik, titik ke garis, dan titik ke bidang).

Materi dimensi tiga merupakan bagian dari geometri yang membahas tentang bangun ruang atau bangun dimensi tiga. Bangun ruang dapat didefinisikan sebagai bangun yang tidak seluruhnya terletak pada bidang karena terdiri dari tiga unsur yaitu panjang, lebar, dan tinggi, atau sering juga disebut dengan geometri dimensi tiga (Negoro\&Harahap, 2014). Geometri dimensi tiga membahas mengenai objek-objek yang bersifat abstrak. Objek-objek tersebut seperti titik garis, bidang, kubus, balok, bola, dan sebagainya dimana kesemuanya adalah objek-objek yang didapatkan melalui proses abtraksi berdasarkan benda-benda konkret yang terdapat dalam kehidupan sehari-hari (Clements \& Sarama, 2011; Couto \& Vale, 2014)

Menurut teori van Hiele, siswa akan melalui lima tingkat berpikir dalam mempelajari dan memahami geometri, yang terdiri: tingkat 0 (visualisasi), tingkat 1 (analisis), tingkat 2 (dedu ksi informal), tingkat 3 (deduksi), dan tingkat 4 (rigor), (Alex \& Mammen, 2012). Geometri merupakan bidang yang sangat penting dalam matematika, dari sudut pandang matema tika, geometri merupakan pendekatan untuk memecah kan masalah, misalkan gambar-gambar, diagram, sistem koordinat, vektor, serta transformasi. Sedangkan berdasarkan sudut pandang psikologi, geometri merupakan penya jian abstraksi dari pengalaman visual, misalnya bidang, pola, pengu kuran, dan pemetaan (Risnawati, 2012).

Teknologi pembelajaran matematika merupakan sarana yang penting untuk membe lajarkan matematika secara efektif, tehnologi dapat memperluas matematika yang dapat diajar kan dan meningkatkan prestasi belajar siswa. Dalam komputer dapat digunakan pada materi matematika yang memerlukan visualisasi, misalnya geometri. GeoGebra merupakan pro gram komputer yang dinamis, dapat digunakan untuk pembelajaran matematika, terutama pada geometri. GeoGebra memiliki fasilitas untuk memvisualisasikan atau mendemonstrasikan konsep-konsep matematika serta sebagai alat bantu untuk mengkontruksi konsep-konsep matematika(Syahbana; 2016:2).

Kenyataan yang terjadi di sekolah bahwa materi Dimensi Tiga merupakan salah satu materi yang dirasa paling sulit bagi siswa. Demikian juga dari ungkapan bapak ibu rekan guru saat pertemuan MGMP, bahwa daya serap siswa pada kompentesi ini sangatlah rendah. Setingkat mahasiswa pun masih mengalami kesulitan belajar geometri deminsi tiga (Novita $\mathrm{R}$; 2018). Hal ini tercermin juga dari hasil ulangan harian dimensi tiga siswa kelas XII_MIPA SMA Negeri 1 Kediri, tahun pelajaran 2018/2019 rata-ratan 5,90, dengan menggunakan Kriteria Ketuntasan Minimal (KKM) 75 , tentunya hasil ini masih sangat jauh dari harapan.

Adapun rendahnya hasil belajar matematika di kelas XII_MIPA, SMA Negeri 1 Kediri, khususnya pada materi dimensi tiga disebabkan oleh beberapa faktor, baik faktor siswa maupun guru. Siswa beranggapan bahwa matematika sulit, hal ini karena matematika merupakan pelajaran yang mempunyai objek kajian yang abstrak yaitu berupa fakta, konsep, ketrampilan dan prinsip, serta banyak rumus. Motivasi belajar siswa yang rendah, ini dapat dilihat dari cara siswa dalam mengikuti pelajaran, yaitu, siswa tidak begitu memperhatikan pada waktu pelajaran, siswa senantiasa pasrah bila diberi soal-soal latihan, siswa kurang percaya diri. Dari faktor guru: Guru kurang mempersiapkan pengajaran secara matang, belum menemukan atau menggunakan metode pengajaran yang tepat, guru cenderung menggunakan metode ceramah dan latihan soalsoal saja.

Salah satu model pembelajaran yang dapat menumbuhkan kreativitas siswa dalam mengajukan masalah dan memecahkan masalah adalah model pembelajaran sinektik. Model pembelajaran ini adalah model pembelajaran yang menggunakan analogi metafor (kiasan) untuk dapat meningkatkan kemampuan berpikir kreatif siswa baik individu maupun kelompok, melalui sinektik, siswa dapat belajar strategi yang bermakna untuk pemecahan masalah. Keberhasilan penerapan model pembelajarn sinektik telah ditunjukkan oleh beberapa peneliti diantaranya, Mahandari dkk (2013) dengan judul "Pengaruh model pembelajaran sinectik berbantuan media benda konkret terhadap hasil belajar Jembrana", dan Rahmat (2013), "Penerapan model pembelajaran sinektik untuk meningkatkan kemampuan representasi dan komunikasi matematis siswa SMP." Efektifitas 
penggunaan media GeoGebra dan Wingeon pada pembelajaran materi dimensi tiga (Putrisar, 2019). Efektifitas penggunaan GeoGebra pada materi dimensi, Niken (2017).

Berdasarkan uraian dari permasalahan di atas maka tujuan penelitian ini adalah untuk mengetahui peningkatkan hasil belajar siswa pada materi dimensi tiga melalui penerapan model pembelajaran sinektik dengan menggunakan media pembelajaran GeoGebra.

\section{METODE PENELITIAN}

Penelitian ini merupakan jenis penelitian tindakan kelas yang terdiri dari dua siklus, masing-masing siklus terdiri dua pertemuan. Penelitian dilaksanakan di SMA Negeri 1 Kediri Jl.Veteran no.1 Kota Kediri Jawa Timur.

Subyek penelitian tindakan kelas ini adalah siswa kelas XII_IPA_H tahun pelajaran 2019/2020 semester gasal, yang berjumlah 32 siswa terdiri dari 18 laki-laki dan 14 perempuan. Adapun obyek penelitiannya mata pelajaran Matematika Wajib materi Dimensi Tiga (KD 3.1 dan KD 4.1).

Data penelitian terdiri: (1) data kuantitatif, yaitu data hasil belajar siswa (pos tes) siklus 1, dan siklus 2, serta (2) data kualitatif, yaitu aktivitas belajar yang terdiri dari data aktivitas belajar siswa pada jurnal refleksi siklus I, data aktivitas belajar siklus II pada lembar observasi.

Teknik pengumpulan data penelitian yaitu: (1) teknik tes, (2) teknik pengamatan, dan (3). teknik dokumentasi. Teknik tes tertulis digunakan untuk memperoleh data hasil belajar pada siklus 1 dan 2 yang dilaksanakan pada tiap akhir siklus.. Teknik pengamatan atau observasi digunakan untuk memperoleh data aktivitas belajar siswa pada siklus 1 dan 2 . Pengamatan dan observasi dilakukan oleh teman sejawat selaku kolaborator yang bertugas mengamati aktivitas siswa dengan memberikan check list pada lembar observasi. Teknik dokumentasi berupa jurnal refleksi pembelajaran digunakan untuk mencari data kondisi awal aktivitas belajar dan hasil belajar. Dokumentasi aktivitas belajar dapat dilihat jurnal mengajar guru

Alat pengumpulan data penelitian menggu nakan dokumen daftar nilai, dokumen catatan personal, lembar observasi, dan tes tertulis. Dokumen daftar nilai digunakan untuk memperoleh data hasil belajar pada kondisi awal, Dokumen catatan personal siswa dan jurnal mengajar guru untuk memperoleh data aktivitas belajar kondisi awal. Lembar observasi / penga matan digunakan untuk mencari data aktivitas belajar siswa pada siklus 1 . Butir soal tes tertulis digunakan untuk mengukur hasil belajar pada siklus 1 dan siklus 2. Lembar observasi diguna kan untuk mencari data aktivitas belajar pada siklus 2.

Analisis data dilakukan melaui: 1) teknik kualitatif dan teknik kuantitatif. Teknik kualitatif di gunakan untuk menganalisis aktivitas belajar siswa, sedangkan teknik kuantitatif digunakan untuk menganalisis data hasil belajar siswa.

Indikator kinerja dalam penelitian dilihat dari peningkatan hasil belajar siswa melalui penerapan model pembelajaran sinektik menggu nakan media pembelajaran GeoGebra pada materi dimensi tiga. Indikator keberhasilan ditunjukkan dengan: Siswa yang memperoleh nilai hasil belajar $\geq 75$, sebanyak $\geq 85 \%$.

Metode Penelitian Tindakan Kelas terdiri dari 2 siklus. Dalam setiap siklus tindakan saling berkaitan. Pada siklus 1 dan 2 pembelajaran dilakukan dengan penerapan model pembelajaran sinektik menggunakan media pembelajaran GeoGebra pada materi dimensi tiga. Siklus 1 dan 2 berlangsung 4 pertemuan. Variabel yang diteliti sebagai tindakan adalah penerapan model pembelajaran sinektik menggunakan media pembelajaran GeoGebra pada materi dimensi tiga serta sebagai hasil yang dicapai adalah hasil belajar.

Adapun langkah-langkah penelitian disajikan pada gambar berikut.

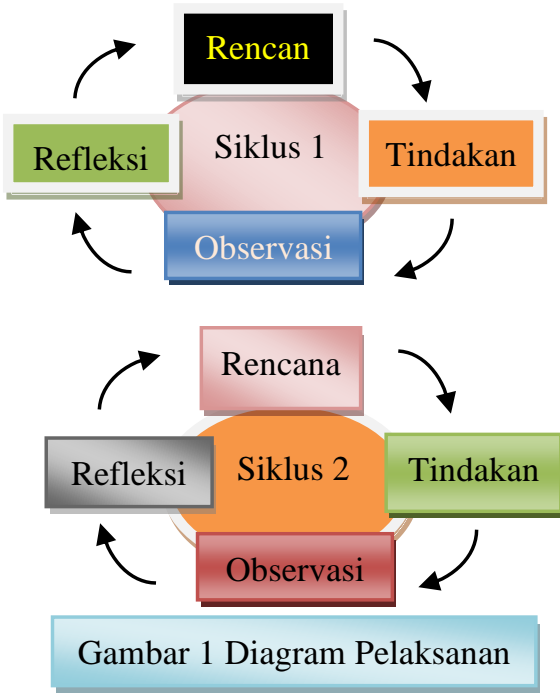

\section{HASIL DAN PEMBAHASAN}

Model pembelajaran sinektik adalah model pembelajaran yang menggunakan analogi metafor (kiasan) untuk meningkatkan kemam puan berpikir kreatif siswa baik individu maupun kelompok, melalui sinektik siswa dapat belajar strategi yang bermakna untuk pemecahan masa 
lah. Ada dua strategi dari model pembelajaran sinektik, yaitu strategi pertama: pembelajaran untuk melazimkan terha dap sesuatu yang masih asing (making the strange familiar), dan strategi kedua: pembelajaran untuk menciptakan sesuatu yang baru (creating something new).

Strategi pertama model pembelajaran sinektik misalnya digunakan untuk mengajarkan penyelesaian dari keliling dan luas persegi panjang menggunakan definisi dari keliling dan luas dengan menganalogikan pada cara menye lesaikan keliling dan luas persegi yang telah dipelajari siswa sebelumnya. Dalam strategi ini, ketika menganalogikan cara menyelesaikan keliling dan luas persegipanjang dengan keliling dan luas persegi menggunakan definisi keliling dan luas, siswa diminta untuk menganalisis. Pada strategi kedua model pembelajaran sinektik misalnya digunakan untuk mengajarkan materi dimensi tiga (bangun ruang) dengan meng analogikan pada materi dimensi dua (bangun datar) yang telah dipelajari siswa sebelumnya. Dalam strategi ini, analogi digunakan untuk menciptakan jarak konseptual sehingga dapat membantu siswa untuk membangun pemahaman terhadap materi baru, yaitu materi dimensi tiga. Dalam pembelajaran sinektik terdapat analogi. Analogi adalah suatu perbandingan yang digunakan untuk membuat suatu konsep yang sulit menjadi jelas. Dalam menggunakan analogi, kita menghubungkan dua peristiwa yang sejenis. dan mempunyai persamaan prinsip, sehingga dalam penyimpulan analogi terdapat tiga unsur, yaitu:

a. peristiwa pokok yang menjadi dasar analogi,

b. persamaan prinsipal yang menjadi pengikat

c. fenomena yang akan dianalogikan.

Adapun tahapan model pembelajaran sinektik pada srategi pembelajaran untuk menciptakan sesuatu yang baru (creating something new), dikemukakan oleh Gordon adalah:

Tabel 1 Tahapan Model Pembelajaran Sinektik

\begin{tabular}{ll}
\hline Tahapan & Kegiatan Guru \\
\hline Pertama & Guru memberikan informasi \\
Input Substansif & topik baru. \\
\hline Kedua & $\begin{array}{l}\text { Guru mengajukan analogi } \\
\text { Analogi Langsung } \\
\text { langsung dan meminta siswa } \\
\text { untuk menguraikan analogi } \\
\text { tersebut. }\end{array}$ \\
\hline Ketiga & $\begin{array}{l}\text { Guru meminta siswa untuk } \\
\text { Analogi Personal }\end{array}$ \\
\hline Keempat & $\begin{array}{l}\text { Siswa mengidentifikasi dan } \\
\text { menjelaskan point-point } \\
\text { Membandingkan } \\
\text { Analogi }\end{array}$ \\
& $\begin{array}{l}\text { kemiripan antara materi baru } \\
\text { dengan analogi langsung. }\end{array}$ \\
\hline Kelima & Siswa menjelaskan dimana \\
\hline &
\end{tabular}

\begin{tabular}{ll}
\hline Tahapan & Kegiatan Guru \\
\hline $\begin{array}{l}\text { Menjelaskan } \\
\text { berbagai perbedaan }\end{array}$ & analogi tidak cocok. \\
\hline $\begin{array}{l}\text { Keenam } \\
\text { Eksplorasi }\end{array}$ & $\begin{array}{l}\text { Siswa menjelaskan kembali } \\
\text { topik semula dengan } \\
\text { bahasanya sendiri }\end{array}$ \\
\hline Ketujuh & $\begin{array}{l}\text { Siswa menyediakan analogi } \\
\text { Memunculkan }\end{array}$ \\
langsung mereka sendiri dan \\
menalogi Baru & $\begin{array}{l}\text { menelidiki kemi-ripan dan } \\
\text { perbedaannya. }\end{array}$ \\
\hline
\end{tabular}

Pelaksanaan pembelajaran pada siklus I

1. Sebagai apersepsi guru mengaitkan pengertian jarak dua titik, dan jarak titik ke garis pada bidang datar, proyeksi, dan garis saling tegak lurus.

2. Tahap 1: Input Substansif, dengan meng gunakan LCD dan visualisasi gambar dengan GeoGebra guru menjelaskan pengertian jarak dua titik dan jarak dari titik ke garis dalam ruang dimensi tiga.

3. Tahap2: Analogi langsung, siswa masuk dalam kelompok masing-masing (tiap kelopok 3 orang dengan 1 laptop). Siswa dalam kelom pok diminta untuk membuat sebuah analogi dari permasalahan yang diberikan, misalnya: Jarak dua titik dalam ruang dianalogikan sebagai jarak dua titik pada bidang datar (Segitiga siku-siku). Dan jarak titik ke garis dalam ruang dianalogikan bidang datar (segitiga) yang memuat titik dan garis tersebut.

4. Tahap 3: Analogi personal, Siswa diminta untuk membuat sebuah analogi personal dari analogi yang telah dibuat sebelumnya, misal: Posisi dari kedua titik yang dicari jaraknya terletak pada bidang apa, kemudian segitiga siku-sikunya apa. Dan bidang apa yang memuat titik dan garis yang dicari jaraknya, kemudian segitiga apa yang menunjukkan jarak antara titik dan garis tersebut. Hal ini dimung-kinkan masing-masing siswa berbeda dalam mengambil segitiga yang memuat titik dan garis tersebut.

5. Tahap 4: Membandingkan analogi, pada tahap ini, guru berusaha untuk memunculkan perbedaan mendasar antara bangun ruang dan bangun datar. Siswa diminta untuk menyatakan perbedaan antara cara menentukan jarak dua titik pada bidang datar dan jarak dua titik dalam ruang. Demikian juga jarak titik ke garis pada bidang datar dan di ruang.

6. Tahap 5: Menjelaskan berbagai perbe daan, siswa diminta untuk menjawab pertanyaan yang menunjukkan sebuah konflik yang ditekan, yaitu: "Bidang datar apakah yang memuat titik dan garis yang 
dicari jaraknya, dan segitiga apa yang menunjukkan jarak antara titik dan garis tersebut?

7. Tahap 6 : Eksplorasi, siswa diminta men jelaskan cara menentukan jarak dua titik dan jarak titik ke garis dalam ruang menurut bahasanya siswa sendiri.

8. Tahap 7 : Memunculkan analogi baru, di berikan permasalahan baru yang berkaitan dengan jarak titik ke garis.

Pada akhir proses belajar mengajar siswa diberi Pos tes 1, dengan tujuan untuk mengetahui tingkat keberhasilan siswa dalam proses belajar mengajar yang telah dilakukan. Adapun data hasil penelitian pada siklus I adalah sebagai berikut:

Tabel 2. Analisis Diskriptip Pretes dan Pos tes

\begin{tabular}{ccccc}
\hline Siklus 1 & $\begin{array}{l}\text { Rata- } \\
\text { rata }\end{array}$ & Min & Max & $\begin{array}{c}\text { Standart } \\
\text { Deviasi }\end{array}$ \\
\hline Pre tes-1 & 55 & 30 & 70 & 10 \\
\hline Pos tes-1 & 80,6 & 50 & 90 & 9,3 \\
\hline
\end{tabular}

Dari hasil analisis diskriptip terlihat bahwa, hasil pos tes meningkat cukup siqnifikan dibandingkan dari hasil pre tes baik nilai minimalnya, maupun rata-ratanya. Standar deviasi pos tes lebih kecil dibanding standar deviasi pre tes, hal ini menun jukkan bahwa penyebaran nilai pos tes lebih kecil dibandingkan penyebaran nilai pre tes. Terdapat 26 orang siswa mendapat nilai lebih dari 75 , dengan menggunakan KKM sebesar 75, ketuntasan klasikal 81,75\%, berarti masih ada 6 orang siswa $(18,75 \%)$ yang belum tuntas. Adapun dari analisis hasil ulangan masih banyak siswa yang terkecoh oleh pilihan jawaban yang ada. Terdapat juga kesalahan dalam ketelitian menghitungnya, jadi siswa tersebut sebenarnya sudah memahami tentang konsep yang dipelajari, namun dalam menghitung mengalami kesalahan, terdapat 2 siswa yang salah konsep. Memang kedua siswa ini sejak kelas $\mathrm{X}$ memerlukan perhatian khusus.

Dari pengamatan kinerja guru dalam me ngelola dan melaksanakan kegiatan pembelajaran model sinektik dengan menggunakan media pembe lajaran GeoGebra pada siklus pertama, kemampuan guru dalam mengelola pembelajaran sebesar 77,5 \% dengan rata-rata untuk kesepuluh aspek 3,1. Komunikasi matematik pada aspek berdiskusi tentang materi matematik 78,13\% pada menit ke-50. Aktivitas siswa selama mengikuti pembelajaran dikelas sebesar 79,17\% dengan rata-rata untuk keenam aspek adalah 3,17. Dari hasil frekuensi jawaban siswa mengenai refleksi siswa terhadap pembelajaran 88,9 \% siswa merasa senang dengan penampilan guru dalam mengajar matematika, 72,2\% siswa merasa senang dengan suasana pembe lajaran saat itu, $79,1 \%$ siswa mudah mengikuti materi pembelajaran matematika.

Pengamatan kegiatan proses pembe lajaran pada siklus I, tentang materi jarak titik ke garis. Siswa dapat merasakan manfaat GeoGebra dalam menampilkan gambar ruang, seperti kegiatan pembelajaran yang mengacu RPP-2 dan LKS_2, sebagai berikut. Diberikan kubus ABCDEFGH, dengan rusuk $=4 \mathrm{~cm}$, tentukan jarak antara titik $\mathrm{H}$ ke garsis CE.
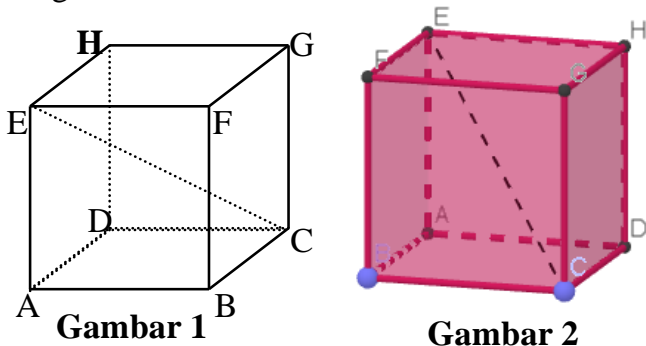

Gambar 2

Tanpa menggunakan tampilan Geogebra, banyak siswa yang terkecoh bahwa jarak antara titik $\mathrm{H}$ dengan garis $\mathrm{CE}$ adalah $\mathrm{EH}$, seolah-olah $\mathrm{CE}$ tegak lurus dengan EH. Namun setelah dioperasikan kuntruksi gambar pada tampilan GeoGebra, siswa baru jelas bahwa ternyata CE tidak tegak lurus EH. Seperti tampilan pada Gambar 2. Dengan menggunakan sintak model pembelajaran sinektik:

$>$ Analogi langsung: jarak titik $\mathrm{H}$ ke garis CE, lihat segitiga $\mathrm{CEH}$..

> Analogi personal : ternyata segitiga $\mathrm{CEH}$ siku-siku di $\mathrm{H}$, pada gambar 3 berikut.

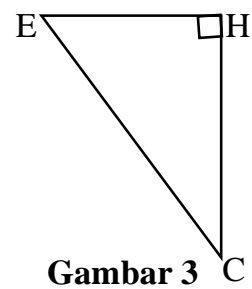

Tahap 4: dibuat garis tinggi dari $\mathrm{H}$ ke $\mathrm{CE}$ yaitu MH, lihat gambar 4.

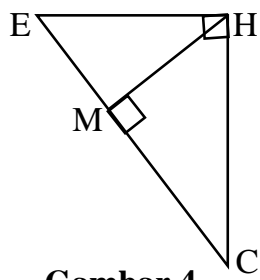

Tahap 5 : jarak yang dicari adalah HM dihitung menggunakan phytagoras atau cara lain. 
Tahap 6: siswa menjelaskan mengapa jarak nya Ruas garis HM.

Tahap 7: siswa mengerjakan soal, seperti per masalahan yang ada pada LKS-2.

Pada akhir proses pembelajaran Siklus II didapatkan data sebagai berikut.

Tabel 3. Analisis Diskriptip Pretes dan Pos tes

\begin{tabular}{ccccc}
\hline Siklus II & $\begin{array}{c}\text { Rata- } \\
\text { rata }\end{array}$ & Min & Max & $\begin{array}{c}\text { Standart } \\
\text { Deviasi }\end{array}$ \\
\hline Pre tes-2 & 56,9 & 40 & 70 & 8,45 \\
\hline Pos tes-2 & 75 & 40 & 90 & 11,4 \\
\hline
\end{tabular}

Dari tabel 3 terlihat tedapat peningkatan antara rata-rata hasil pre tes dengan pos tes, demikian juga nilai maximumnya. Standart deviasi pre tes lebih kecil dibanding pos tes, ini menunjukkan penye baran hasil pos tes relatif besar. Terdapat 24 siswa yang mendapat nilai lebih dari 75 , berarti terdapat 8 siswa yang belum tuntas $(25$ $\%)$. Jadi ketuntasan klasikal baru dicapai sebesar $75 \%$.

Dari pengamatan kinerja guru dalam me ngelola dan melaksanakan kegiatan pembelajaran model sinektik dengan menggunakan media pembe lajaran GeoGebra pada siklus kedua, kemampuan guru dalam mengelola pembelajaran sebesar meningkat dari 77,5\% di siklus I menjadi $82,5 \%$ dengan rata-rata untuk kesepuluh aspek 3,3. Komunikasi matematik pada aspek berdiskusi ten tang materi matematik tetap sama hasil di siklus I, sebesar 78,13\% pada menit ke40. Aktivitas siswa selama mengikuti pembe lajaran dikelas meningkat dari 79,17 \% pada siklus I menjadi 83,3 \% di siklus II. Dari hasil frekuensi jawaban siswa mengenai refleksi siswa terhadap pembelajaran sama dengan hasil pada siklus I, yaitu 88,9 \% siswa merasa senang dengan penampilan guru dalam mengajar, 72,2 \% siswa merasa senang dengan suasana pembe lajaran saat itu, 79,1\% siswa mudah mengikuti materi pembelajaran matematika.

Pengamatan kegiatan proses pembelaja ran pada siklus II, tentang materi jarak garis ke bidang. Siswa dapat merasakan manfaat media GeoGebra
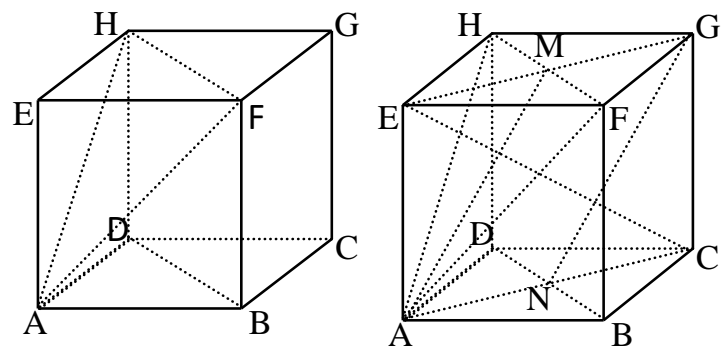

Gambar 5
Diberikan kubus ABCDEFGH, dengan rusuk $=4$ $\mathrm{cm}$, tentukan jarak antara garsis BD dengan bidang AFH. Permasalahan ini dapat di gambarkan secara manual seperti pada gambar 5 . Dari permasalahan diatas, dari setiap kelompok membuat tampilan dengan GeoGebra seperti pada gambar 6, dengan memutar gambar tersebut masing-masing kelompok akan dapat memahami dengan jelas posisi garis BD dengan bidang AFH.

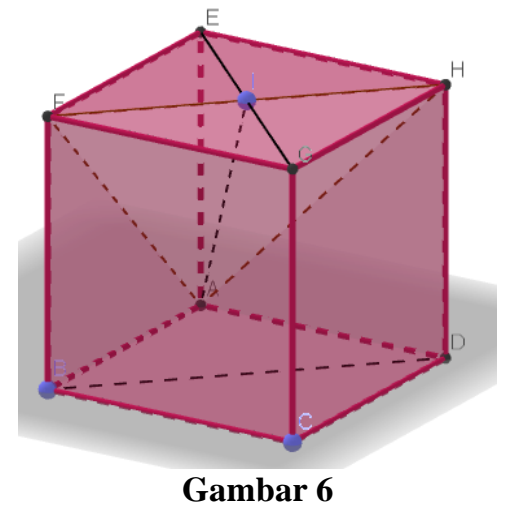

Setelah memahami bahwa posisi garis BD sejajar dengan bidang AFH, maka dilanjutkan membuat kontruksi gambar seperti tampilan pada gambar 7 . Dari tampilan GeoGebra pada gambar 7, dapat diperhatikan dan difahami bahawa bidang AFH sejajar dengan bidang BDG.

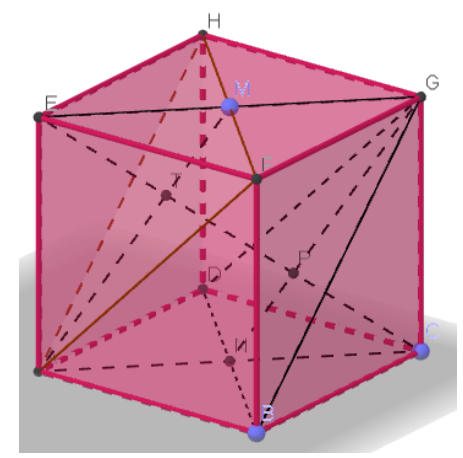

Gambar 7

Dengan mengerakkan gambar 7, maka didapatkan posisi seperti pada gambar 8, yang menyatakan bahwa jarak antara garis BD dan bidang AFH diwakili oleh jarak antara garis AM dan garis NG.

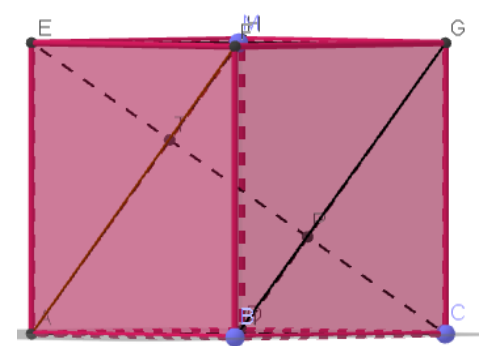

Gambar 8 
Dengan memperhatikan gambar 8, maka masingmasing kelompok dapat membuat gambar bangun datar persegi panjang ACGE, seperti gambar 9

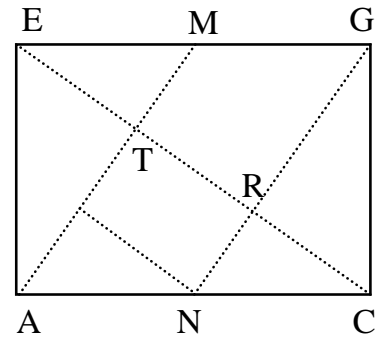

Gambar 9

Jarak antara garis BD dengan bidang AFH adalah ruas garis TR.

Dari uraian pelaksanaan proses pembe lajaran diatas nampaklah bahwa model pembe lajaran sinektik dengan media pembelajaran GeoGebra sangat diperlukan khususnya pada materi dimensi tiga.

Adapun data pos tes pada siklus I dan siklus II dapat nyatakan sebagai berikut.

Tabel 4. Analisis data Pos tes-1 dan Pos tes-2

\begin{tabular}{lcccc}
\hline $\begin{array}{l}\text { Siklus } \\
\text { dan II }\end{array}$ & $\begin{array}{l}\text { Rata- } \\
\text { rata }\end{array}$ & Min & Max & $\begin{array}{l}\text { Standart } \\
\text { Deviasi }\end{array}$ \\
\hline Pos tes-1 & 80,6 & 50 & 90 & 9,3 \\
\hline Pos tes-2 & 75 & 40 & 90 & 11,4 \\
\hline
\end{tabular}

Apabila kita perhatikan tabel di atas bahwa hasil pos tes-1 lebih baik dibandingkan dengan hasil pos tes-2, baik rata-rata, nilai minimum maupun nilai maksimumnya. Demikian juga jumlah ketuntasan belajarnya pada siklus I sebesar 81,75 $\%$, dan siklus II $75 \%$. Hal ini terjadi bahwa materi pada siklus I tingkat kesulitannya tidak sama dengan materi pada siklus II. Semua konsep yang dibahas di siklus I merupakan kompetensi prasyarat untuk materi di siklus II, artinya pemehaman siswa pada materi siklus I, menjadi dasar untuk dapat memahami materi siklus II. Materi siklus II masih memerlukan kemampuan abstraksi dan penalaran yang lebih tinggi lagi, karena permasalahannya lebih komplek.

Apabila kita bandingkan dengan beberapa hasil penelitian tentang materi demensi tiga, diantaranya: hasil penelitian yang dilakukan oleh Jurotun (2019), dengan model pembelajaran PBL berbantuan alat peraga seder hana berbahan limbah sedotan dapat meningkat kan hasil belajar siswa dengan nilai rata-rata mencapai 75,44 dengan jumlah siswa yang tuntas mencapai $86,84 \%$. Penelitian Niken (2017) dengan judul efektifitas penggunaan GeoGebra pada materi
Dimensi tiga, walaupun mendapatkan hasil efektif namun nilai hasil belajar yang didapat rata-ratanya hanya 74,86 , dengan ketuntasan 80 $\%$.

Dengan hasil yang didapat pada siklus I maupun siklus II yang telah diuraikan diats, dan dengan membandingkan hasil dari para peneliti lain, bahwa menurut peneliti adalah suatu hasil yang cukup memuaskan, walaupun belum bisa memenuhi ketuntasan belajar sebesar $85 \%$. Demikian juga dari hasil observasi, secara umum terdapat peningkatan dari siklus I ke siklus II.

\section{SIMPULAN}

Berdasar data-data hasil penelitian yang telah diuraian diatas dan dengan memperhatikan hasil penelitian-penelian yang sejenis maka dapat ditarik kesimpulan bahwa penerapan model pembelajaran sinektik menggunakan media pembelajaran GeogGebra pada materi dimensi tiga dapat meningkatkan hasil belajar siswa. Walaupun nilai hasil belajar baik pada siklus I maupun siklus II, belum memenuhi kriteria ketuntasan belajar, namun perolehan nilai dengan rata-arata 80,6 pada siklus I dan 75 pada siklus II bagi peneliti adalah sudah sangat memuaskan. Hasil pengamatan selama proses pembelajaran, menunjukkan adanya peningkatan keaktifan siswa, demikian juga siswa merespon positif atas penerapan pembelajaran tersebut. Dan yang lebih penting lagi adalah bagaimana permasalahan soal dimensi tiga dengan gambar ruang yang sangat sulit dibayangkan, dapat di perjelas dengan tampilan gambar kontrusi Geogebra, sehingga mudah difahami. Demikian pula dengan mengikuti sintak model pembelajaran sinektik, siswa dapat merinci, menganalogikan dari permaslahan gambar ruang disederhanakan menjadi bidang datar, yang selanjutnya dapat mempermudah dalam menghitung dengan konsep pythagoras, maupun perbandingan trigonometri yang lebih sederhana.

\section{DAFTAR PUSTAKA}

Akanmu, I. A. 2016."Geogebra: An Effective Package for Mathematics Instruction in Negeria".

Clements, D. H., dan Sarama, J. 2011. Early childhood teacher education: The case of geometry. Journal of Mathematics Teacher Education, 14(2): 133-148.

Alex dan Memmen. 2012. A Survey of South African Grade 10 Learners' Geometric Thinking Levels in Terms of The Van Hiele Theory. Anthropologist, 14(2): 123-129. 
Ferdianto, Ferry. 2010. Pembelajaran geometri berdasarkan tahap berpikir Van Hiele. http://ferrymath.blogspot.com. Akses pada 21 Agustus 2017

Gumilar. 2012. Pembelajaran geometri dengan Wingeom untuk meningkatkan kemam puan spasial dan penalaran matematis siswa. Tesis, SPs UPI. Tidak diterbitkan.

Mahandari, Jayanti, Parmiti, Putu dan. Jampel, I. Nym. 2013. Pengaruh model pembe lajaran sinectik berbantuan media benda konkret terhadap hasil belajar. Jembrana, 11.

Jumriani. 2014. Analisis Tingkat Berpikir Siswa Berdasarkan Teori Van Hiele pada Materi Pokok Dimensi Tiga Ditinjau dari Gaya Kognitif Kelas X SMA Negeri 1 Kahu. Tesis. Universitas Negeri Makassar, Tidak diterbitkan.

Kariadinata, R. 2010. Aplikasi Berbasis Komputer dalam Pembelajaran Matematika. Disertasi Jurusan Pendidikan Matematika SPs UPI Bandung. Tidak diterbitkan.

Kartono. 2012. Hands on Activity pada Pembelajaran Geometri Sekolah sebagai Asesmen Kinerja Siswa. Jurusan Matematika FMIPA UNNES.

Negoro, S. T., dan Harahap, B. 2014. Ensiklopedia matematika. Ghalia Indonesia.

Novita, R., Prahmana, R., Fajri, N., \& Putra, M. 2018. Penyebab Kesulitan Belajar GeomeTri Dimensi Tiga. Jurnal Riset Pendidikan Matematika, 5(1): 18-29.

Rahmat Saepuloh, Asep. 2013. Penerapan model pembelajaran sinektik untuk meningkatkan kemampuan representasi dan komunikasi matematis siswa SMP. Universitas Pendidikan Indonesia

Risnawati. 2012. Pengaruh Pembelajaran dengan Pendekatan Induktif-Deduktif Berbantuan Program Cabri Geometry terhadap PeningKatan Kemampuan Representasi Matematis siswa SMP. Tesis SPs UPI. Bandung. Tidak Diterbitkan.

Syahbana, Ali. 2016. Belajar Menguasai Geo Gebra. Palembang: NoerFikri Offset. 